\title{
PENGARUH PENGgUNAAN BENTONIT TERAKTIVASI ASAM SEBAGAI KATALIS TERHADAP PENINGKATAN KANDUNGAN SENYAWA ISOPULEGOL PADA MINYAK SEREH WANGI KABUPATEN GAYO LUES - ACEH
}

\author{
Siti Mahmudha*, Irwan Nugraha \\ Program Studi Kimia, Fakultas Sains dan Teknologi, Universitas Islam Negeri Sunan Kalijaga, Jl. Marsda \\ Adisucipto, Yogyakarta 55281 \\ *Alamat Korespondensi: mumuddhah@gmail.com
}

\begin{abstract}
Abstrak: Studi yang bertujuan untuk mengetahui pengaruh penggunaan bentonit teraktivasi asam sebagai katalis terhadap peningkatan kandungan senyawa isopulegol pada minyak sereh wangi Kabupaten Gayo Lues Aceh telah dipelajari. Aktivasi bentonit dilakukan dengan menggunakan larutan $\mathrm{H}_{2} \mathrm{SO}_{4} 0,6 \mathrm{M}, \mathrm{HCl}$ 0,5 $\mathrm{M}$ dan $\mathrm{HNO}_{3}$ 0,1 M. Hasil aktivasi dikarakterisasi menggunakan Fourier Transform Infrared (FT-IR) dan X-Ray Difraction (XRD). Reaksi minyak sereh wangi dengan bentonit alam dan bentonit teraktivasi asam dilakukan selama 30 menit pada suhu $30^{\circ} \mathrm{C}$. Produk yang dihasilkan di analisis menggunakan Gas Chromatography-Mass Spectroscopy (GC-MS). Hasil penelitian menunjukkan bahwa penggunaan bentonit berperan sebagai katalis dalam peningkatan kandungan senyawa isopulegol yang merupakan isolat dari senyawa sitronellal. Sitronellal adalah salah satu senyawa monoterpena yang dapat mengalami reaksi siklisasi dengan katalis homogen dan heterogen. Kandungan isopulegol mengalami peningkatan dari $12,66 \%$ menjadi $14,05 \%$ pada bentonit alam; $30,11 \%$ pada bentonit teraktivasi $\mathrm{H}_{2} \mathrm{SO}_{4} 0,6 \mathrm{M} ; 32,70 \%$ pada bentonit teraktivasi $\mathrm{HCl} 0,5 \mathrm{M}$ dan $14,34 \%$ pada bentonit teraktivasi $\mathrm{HNO}_{3} 0,1 \mathrm{M}$.
\end{abstract}

Kata kunci: bentonit teraktivasi, sitronellal, isopulegol, katalis

Abstract: Study of Effect Acid-Activated Bentonite as Catalyst to Improve Isopulegol of Citronellal Oil from Gayo Lues - Aceh have been studied. Bentonite activation was done by using $\mathrm{H}_{2} \mathrm{SO}_{4} \mathrm{O}, 6 \mathrm{M}, \mathrm{HCl}$ 0,5 $\mathrm{M}$ and $\mathrm{HNO}_{3}$ 0,1 M. The result of activation were characterized by Fourier Transform Infrared (FT-IR) and X-Ray Difraction (XRD). Reaction of citronellal oil with raw bentonite and acid-activated bentonite performed for 30 minutes at $30^{\circ} \mathrm{C}$. The result of products were analized by using Gas Chromatography-Mass Spectroscopy (GC$M S)$. The result showed that using bentonite as a catalyst can improve isopulegol which is isolated from citronellal. Citronellal is one of monoterpene compounds that can undergo reaction of cyclization with homogeneous and heterogeneous catalysts. Isopulegol has been improved from 12,66\% to 14,05\% in raw bentonite; $30,11 \%$ in activated bentonit $\mathrm{H}_{2} \mathrm{SO}_{4} 0,6 \mathrm{M} ; 32,70 \%$ in activated bentonite $\mathrm{HCl} 0,5 \mathrm{M}$ and $14,34 \%$ in activated bentonite $\mathrm{HNO}_{3} \mathrm{O}, 1 \mathrm{M}$.

Keywords: Activated Bentonite, Citronellal, Isopulegol, Catalyst

\section{PENDAHULUAN}

Minyak sereh wangi merupakan salah satu jenis minyak atsiri yang banyak dikembangkan di Indonesia. Minyak sereh wangi merupakan minyak atsiri yang diperoleh dari daun tanaman sereh Cymbopogon winterianus. Minyak sereh wangi mengandung komponen utama yang terdiri dari senyawa sitronellal, sitronellol dan geraniol yang memiliki nilai ekonomis yang besar untuk kepentingan bahan baku fragrance dan industri (Fatimah dkk. 2008).

Minyak sereh wangi memiliki beragam manfaat yang memberikan pengaruh terhadap penggunaannya. Pemanfaatan tersebut tidak didukung dengan pengolahan yang baik. Salah satu sentra produksi minyak sereh wangi terbesar di Indonesia adalah Kabupaten Gayo Lues Provinsi Aceh. Sebagian besar industri minyak sereh wangi di Kabupaten Gayo Lues masih berskala kecil dengan teknologi yang digunakan masih tergolong sederhana dan tradisional. Hal ini tentu saja akan mempengaruhi kandungan senyawa dari minyak sereh wangi tersebut dan tentu akan mempengaruhi nilai jualnya. Menurut Rahman (2015) harga minyak sereh wangi di Kabupaten Gayo Lues hanya berkisar antara Rp. 150.000 - Rp. 160.000 sehingga para petani minyak sereh wangi di wilayah Kabupaten Gayo Lues baru bisa menjual minyak sereh wangi dengan harga rendah padahal dengan pengolahan bahan baku (crude) yang lebih baik akan meningkatkan nilai ekonomis minyak sereh wangi tersebut.

Komponen minyak sereh wangi yang banyak digunakan dalam industri parfum adalah sitronellol dan geraniol, sedangkan sitronellal tidak digunakan secara langsung (Priatmoko \& Sastrohamidjojo 1990), oleh karena itu sitronellal dapat dimanfaatkan dengan cara diolah lebih lanjut agar menjadi bahan yang bermanfaat. Kaniawati dkk. (2004) juga mengatakan bahwa untuk lebih meningkatkan harga jual dan nilai tambah dari minyak sereh wangi, maka minyak sereh wangi perlu diolah menjadi bentuk isolatnya (seperti mentol, isopulegol dan isopulegil asetat) yang masing-masing mempunyai aroma yang 
khas dan melebihi keharuman minyak sereh itu sendiri. Bahan tersebut banyak digunakan dalam berbagai industri seperti parfum, bahan aditif makanan, sabun dan lain-lain.

Proses pengolahan minyak atsiri dapat menggunakan beberapa adsorben maupun katalis salah satunya adalah bentonit. Beberapa penelitian tentang penggunaan bentonit dalam pengolahan minyak atsiri telah banyak dilakukan. Salah satunya adalah penelitian yang dilakukan Purwaningsih dkk. (2012) yang melakukan penelitian tentang penggunaan bentonit teraktivasi asam sebagai katalis dalam proses transesterifikasi minyak kelapa dengan metanol. Selain itu penelitian lain juga dilakukan oleh Marwati dkk. (2005) yang telah melakukan peningkatan mutu minyak daun cengkeh melalui proses pemurnian menggunakan bentonit, hasil penelitian diperoleh bahwa terjadi peningkatan mutu minyak dari yang tidak memenuhi standar menjadi memenuhi SNI (Standar Nasional Indonesia) No. 062387-1998 dan EOA (Essential Oil Assosiation of USA).

Bentonit merupakan mineral yang terdiri dari kristal alumino-silikat terhidrasi yang mengandung kation alkali atau alkali tanah dalam kerangka tiga dimensi. Ion-ion logam tersebut dapat diganti oleh kation lain tanpa merusak struktur bentonit dan dapat menyerap air secara reversible. Bentonit memiliki kemampuan mengembang, sifat penukar ion, luas permukaan yang besar dan mudah menyerap air sehingga memungkinkan penggunaannya sebagai adsorben (Wijaya dkk. 2003). Selain itu adanya keasaman permukaan bentonit terkait dengan asam Brønsted dan asam Lewis memungkinkan penggunaan bentonit sebagai katalis.

Bentonit merupakan salah satu jenis mineral yang memiliki beragam manfaat dalam kehidupan seharihari. Bentonit dapat digunakan sebagai bahan baku pembuatan semen, keramik, kosmetik, krayon serta sebagai adsorben, bleaching earth maupun sebagai katalis heterogen dalam proses pengolahan minyak baik minyak lemak atau minyak atsiri (Murray 2007).

Oleh karena itu, penelitian ini dilakukan untuk mempelajari bagaimana pengaruh penggunaan bentonit alam dan bentonit teraktivasi asam terhadap kandungan senyawa minyak sereh wangi yang berasal dari Kabupaten Gayo Lues Provinsi Aceh sehingga diharapkan dari hasil penelitian ini diperoleh bahan baku yang memiliki kandungan senyawa yang lebih baik sehingga dapat dengan mudah diolah pada proses pengolahan lebih lanjut.

\section{BAHAN DAN METODE Bahan}

Bahan yang digunakan pada penelitian ini antara lain: minyak sereh wangi yang berasal dari hasil penyulingan tradisional di Kabupaten Gayo Lues Provinsi Aceh dan bentonit alam. Sedangkan bahan kimia yang digunakan terdiri dari asam sulfat, asam klorida, asam nitrat dan akuades.

\section{Peralatan}

Alat-alat yang digunakan pada penelitian ini antara lain seperangkat alat refluks, neraca analitik, corong Buchner, pompa vakum, oven, hot-plate, molecular sieve 106 micron , mortar, magnetic-stirer, oven, gelas kimia $50 \mathrm{~mL}$ dan $100 \mathrm{~mL}$, statif dan klem, pengaduk, pipet ukur $5 \mathrm{~mL}$ dan $10 \mathrm{~mL}$, labu ukur $100 \mathrm{~mL}$ dan $250 \mathrm{~mL}$, kertas saring, FourierTransform Infrared (FT-IR) shimadzu Prestige-21, $X$ Ray Difraction (XRD) Shimadzu 600 dan Gas Chromatography Mass Spectroscopy (GC-MS) QP2010S SHIMADZU.

\section{Preparasi dan Aktivasi Bentonit}

Bentonit alam yang digunakan dalam penelitian ini diayak menggunakan pengayak berukuran 106 mikron, selanjutnya bentonit alam hasil pengayakan dikarakterisasi menggunakan FT-IR dan XRD serta dilakukan uji keasaman dan $\mathrm{pH}$ suspensi solid. Kemudian aktivasi bentonit dilakukan dengan cara mengambil sebanyak 10 gram bentonit alam lalu didispersikan kedalam masing-masing $100 \mathrm{~mL}$ larutan asam $\mathrm{H}_{2} \mathrm{SO}_{4} 0,6 \mathrm{M} ; \mathrm{HCl} 0,5 \mathrm{M}$; dan $\mathrm{HNO}_{3}$ 0,1 M kemudian direfluks dan diaduk selama 3 jam pada suhu $70^{\circ} \mathrm{C}$. Hasil dari pengadukan didinginkan kemudian disaring dengan penyaring vakum dan dicuci dengan akuades panas sampai terbebas dari ion sisa asam. Bentonit alam teraktivasi asam kemudian dikeringkan dalam oven pada suhu $100^{\circ} \mathrm{C}-110^{\circ} \mathrm{C}$ selama 3 jam. Setelah kering digerus sampai halus kemudian diayak menggunakan ayakan ukuran 106 micron. Selanjutnya bentonit teraktivasi asam dikarakterisasi kembali menggunakan FT-IR dan XRD dan di lakukan uji keasaman dan $\mathrm{pH}$ suspensi solid.

\section{Uji Kinerja Bentonit terhadap Minyak Sereh Wangi}

Minyak sereh wangi yang digunakan dalam penelitian ini sebelumnya dianalisis kandungan senyawanya menggunakan GC-MS. Kemudian sebanyak $100 \mathrm{~mL}$ minyak sereh wangi dicampur dengan bentonit alam sebanyak 3 gram dan diaduk selama 30 menit pada suhu $30^{\circ} \mathrm{C}$. Setelah itu, minyak disaring dengan kertas saring. Minyak sereh wangi hasil penyaringan ini kemudian di analisis kembali kandungan senyawanya menggunakan GC-MS. Langkah ini juga dilakukan pada bentonit teraktivasi asam $\mathrm{H}_{2} \mathrm{SO}_{4} 0,6 \mathrm{M}, \mathrm{HCl}$ 0,5 M, dan $\mathrm{HNO}_{3} 0,1 \mathrm{M}$.

\section{HASIL DAN PEMBAHASAN Preparasi dan Aktivasi Bentonit}

Bentonit alam dan bentonit teraktivasi asam didapat dengan ukuran 106 micron. Bentonit yang dihasilkan dikarakterisasi menggunakan FTIR dan XRD. Spektroskopi inframerah merupakan metode analisis yang dapat mengkaji struktur lempung. Identifikasi ini dilakukan dengan cara mengetahui keberadaan gugus-gugus fungsional pada struktur 


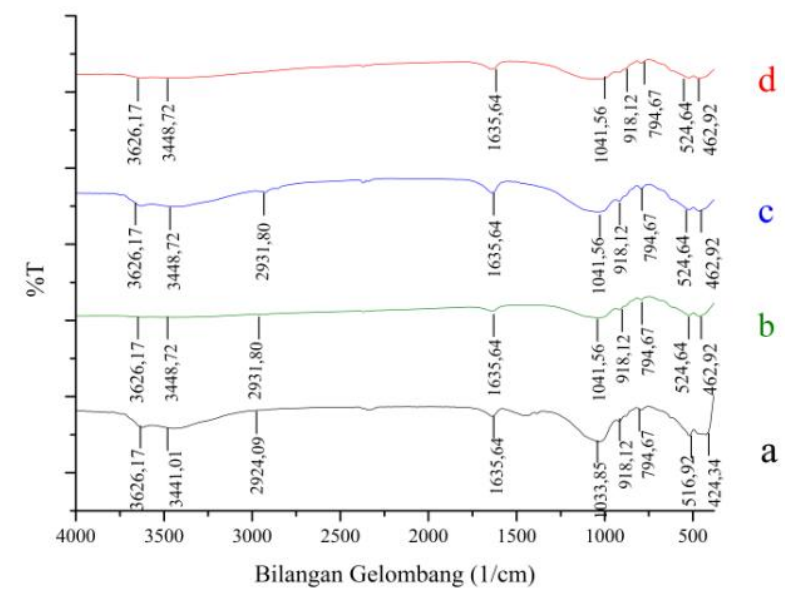

Gambar 1. Spektra FT-IR Bentonit Alam (a), bentonit Teraktivasi $\mathrm{HNO}_{3} 0,1 \mathrm{M}$ (b), bentonit teraktivasi $\mathrm{HCl} 0,5$ $\mathrm{M}$ (c), dan bentonit teraktivasi $\mathrm{H}_{2} \mathrm{SO}_{4} 0,6 \mathrm{M}$ (d)

lempung. Interpretasi data yang dihasilkan hanya bersifat kualitatif karena hanya menampilkan keberadaan gugus-gugus fungsional pada senyawa.

Identifikasi terhadap gugus-gugus fungsional bentonit alam dapat diketahui melalui hasil puncak serapan pada spektra FT-IR. Pita-pita serapan yang khas akan muncul pada bilangan gelombang 3620,1 $\mathrm{cm}^{-1} ; 1636,4 \mathrm{~cm}^{-1} ; 1035,7 \mathrm{~cm}^{-1} ; 794,6 \mathrm{~cm}^{-1} ; 530 \mathrm{~cm}^{-1}$ dan $468,7 \mathrm{~cm}^{-1}$ menunjukkan bahwa salah satu mineral penyusun bentonit adalah montmorillonit (Tan 1982). Hasil spektra FT-IR bentonit alam dan bentonit teraktivasi asam dapat dilihat pada Gambar 1 .

Berdasarkan Gambar 1 pada bentonit alam terdapat bilangan gelombang 3626,17 $\mathrm{cm}^{-1}$ menunjukkan adanya vibrasi ulur dari gugus $\mathrm{OH}$ (gugus hidroksil yang terikat pada $\mathrm{Al}$ dilapisan octahedral Al-Al-OH atau Mg-OH-Al). Bilangan gelombang $3441,01 \mathrm{~cm}^{-1}$ menunjukkan adanya vibrasi ulur gugus $\mathrm{OH}$ yang terhidrasi molekul air yang teradsorbsi. Hal ini diperkuat dengan adanya pita serapan pada bilangan 1635,64 $\mathrm{cm}^{-1}$ yang menunjukkan vibrasi tekuk dari $\mathrm{H}-\mathrm{O}-\mathrm{H}$ dari air yang teradsorpsi didalam bentonit. Adanya pita serapan yang melebar pada bilangan 1033,85 $\mathrm{cm}^{-1}$ menunjukkan karakteristik dari $\mathrm{Si}-\mathrm{O}-\mathrm{Si}$ atau $\mathrm{SiO}_{2}$ (kuarsa), selain itu adanya vibrasi Si-O-Al juga teramati pada bilangan gelombang 794,67 $\mathrm{cm}^{-1}$. Menurut Purwaningsih dkk. (2012) pita serapan pada bilangan gelombang $1041,56 \mathrm{~cm}^{-1}$ sampai $794,67 \mathrm{~cm}^{-}$ ${ }^{1}$ menunjukkan adanya vibrasi ulur asimetris dari SiO. Adanya gugus $\mathrm{Si}-\mathrm{O}$ diidentifikasi dengan munculnya pita serapan yang tajam dan intensitas tinggi pada bilangan gelombang $1033,85 \mathrm{~cm}^{-1}$. Tingginya intensitas pada puncak serapan 1033,85 $\mathrm{cm}^{-1}$ menunjukkan tingginya kandungan montmorillonit pada bentonit. Vibrasi tekuk gugus hidroksil dari Al-OH-Al muncul pada pita serapan
918,12 $\mathrm{cm}^{-1}$, sedangkan vibrasi tekuk dari Si-O-Al dan $\mathrm{Si}-\mathrm{O}-\mathrm{Si}$ ditunjukkan pada bilangan gelombang $519,92 \mathrm{~cm}^{-1}$ dan $424,34 \mathrm{~cm}^{-1}$.

Berdasarkan spektra IR pada Gambar 1 terlihat bahwa terdapat perubahan nilai bilangan gelombang pada spektra bentonit alam dan bentonit teraktivasi asam. Masing-masing spektra memiliki puncak serapan yang hampir sama, hanya saja ada beberapa puncak serapan yang mengalami pergeseran bilangan gelombang, yaitu bilangan gelombang $3441,01 \mathrm{~cm}^{-1}$ yang merupakan vibrasi ulur $\mathrm{OH}$ dari $\mathrm{H}_{2} \mathrm{O}$ mengalami pergeseren menjadi $3425,58 \mathrm{~cm}^{-1}$ pada bentonit teraktivasi $\mathrm{H}_{2} \mathrm{SO}_{4} \quad 0,6 \mathrm{M}$ dan bentonit teraktivasi $\mathrm{HCl} 0,5 \mathrm{M}$ serta menjadi $3448,72 \mathrm{~cm}^{-1}$ pada bentonit teraktivasi $\mathrm{HNO}_{3} 0,1 \mathrm{M}$. Selanjutnya pada bilangan gelombang 1033,85 $\mathrm{cm}^{-1}$ yang merupakan vibrasi ulur asimetris dari Si-O mengalami pergeseran menjadi $1041,56 \mathrm{~cm}^{-1}$ pada bentonit teraktivasi $\mathrm{H}_{2} \mathrm{SO}_{4} 0,6 \mathrm{M}$, bentonit teraktivasi $\mathrm{HCl} 0,5 \mathrm{M}$ dan bentonit teraktivasi $\mathrm{HNO}_{3} 0,1 \mathrm{M}$. Selanjutnya pada bilangan gelombang $519,92 \mathrm{~cm}^{-1}$ dan 424,92 $\mathrm{cm}^{-1}$ yang merupakan vibrasi ulur Si-O$\mathrm{Al}$ dan vibrasi ulur $\mathrm{Si}-\mathrm{O}-\mathrm{Si}$ mengalami pergeseran menjadi $524,64 \mathrm{~cm}^{-1}$ dan $462,92 \mathrm{~cm}^{-1}$ pada bentonit teraktivasi $\mathrm{H}_{2} \mathrm{SO}_{4} 0,6 \mathrm{M}$, bentonit teraktivasi $\mathrm{HCl} 0,5$ $\mathrm{M}$ dan bentonit teraktivasi $\mathrm{HNO}_{3}$ 0,1 M.

Analisis XRD pada bentonit bertujuan untuk mengetahui kandungan mineral-mineral yang terdapat pada bentonit dan melihat pola difraksi pada harga $2 \theta$ dan jarak antar bidang datar (basal spacing) dari kisi kristalin. Difraktogram XRD bentonit alam dan bentonit teraktivasi asam dapat dilihat pada Gambar 2.

Difraktogram XRD bentonit alam (a) pada Gambar 2 menunjukkan puncak dengan intensitas tinggi pada $2 \theta=6,09$ dan $2 \theta=20,27$ dengan basal spacing sebesar $14,48 \AA$ dan $4,38 \AA$ yang mengindikasikan mineral montmorillonit. Hal ini 


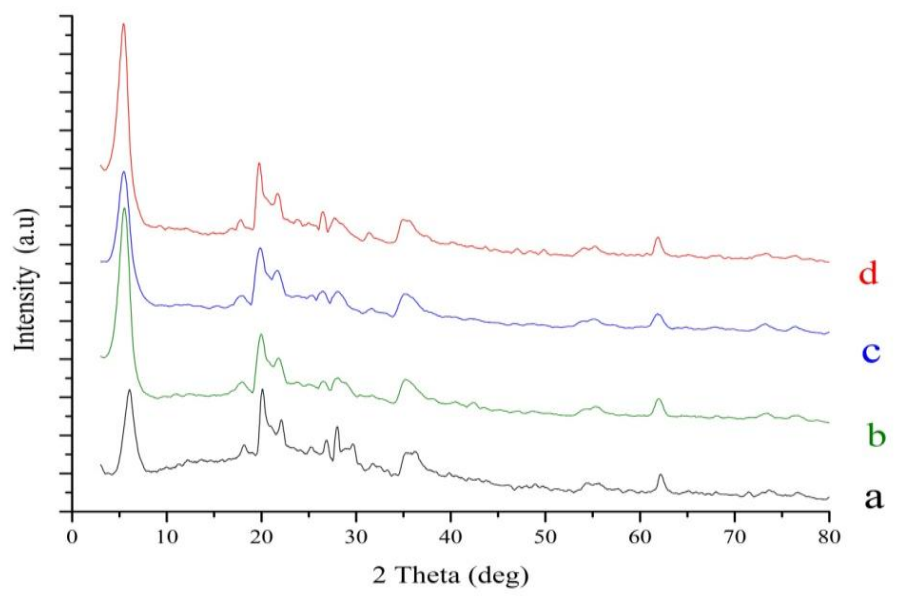

Gambar 2. Difraktogram XRD Bentonit Alam (a), Bentonit Teraktivasi $\mathrm{HNO}_{3} 0,1 \mathrm{M}$ (b), Bentonit Teraktivasi $\mathrm{HCl}$ 0,5 M (c) dan Bentonit Teraktivasi $\mathrm{H}_{2} \mathrm{SO}_{4} 0,6 \mathrm{M}$ (d)

Tabel 1. Data Keasaman Bentonit Alam dan Bentonit Teraktivasi Asam

\begin{tabular}{lc}
\hline \multicolumn{1}{c}{ Jenis Bentonit } & $\begin{array}{c}\text { Keasaman } \\
(\mathbf{m g ~ K O H} / \mathbf{g})\end{array}$ \\
\hline Bentonit Alam & 0 \\
Bentonit Teraktivasi $\mathrm{H}_{2} \mathrm{SO}_{4} 0,6 \mathrm{M}$ & 0,374 \\
Bentonit Teraktivasi $\mathrm{HCl} 0,5 \mathrm{M}$ & 0,375 \\
Bentonit Teraktivasi $\mathrm{HNO}_{3} 0,1 \mathrm{M}$ & 0,375 \\
\hline
\end{tabular}

sesuai dengan ruang d001 dan d100 yang khas pada mineral montmorillonit. Selanjutnya pada $2 \theta=21,68$ dengan basal spacing $4,09 \AA$ dan $2 \theta=31,75$ dengan basal spacing 2,82 menunjukkan adanya mineral kuarsa dan feldspar. Puncak lain terdapat pada $2 \theta=$ 35,79 dengan basal spacing 2,51 $\AA$ yang menunjukkan mineral montmorillonit. Morris, dkk (1981) juga menyatakan bahwa mineral montmorillonit menunjukkan puncak difraksi pada $2 \theta$ $=6.09,20,27$ dan 35,79 dengan basal spacing berturut-turut sebesar $14,48 \AA$, 4,38 $\AA$, dan $2,51 \AA$. Sedangkan mineral kuarsa dan feldspar menunjukkan puncak difraksi pada $2 \theta=21,68$ dengan basal spacing 4,09 $\AA$ dan $2 \theta=31,75$ dengan basal spacing $2,82 \AA$. Berdasarkan difraktogram yang diperoleh dapat disimpulkan bahwa bentonit alam terdiri dari mineral montmorillonit sebagai fasa mineral yang dominan dan beberapa mineral lain seperti kuarsa dan feldspar.

Difraktogram bentonit teraktivasi asam pada Gambar 2 menunjukkan adanya pergeseran harga $2 \theta$ dan jarak antar bidang menjadi lebih kecil (pergeseran kekiri). Pergeseran ini disebabkan karena terjadi reaksi antara bentonit dan asam sehingga menyebabkan terjadinya perubahan luas antar bidangnya. Menurut Priambodo (2012), masuknya kation $\mathrm{H}^{+}$dari asam diantara lapis pada mineral bentonit menggantikan kation penyeimbang muatan lapis silikat pada mineral bentonit menyebabkan ekspansi jarak antara lapis silikat montmorillonit.
Ekspansi ini terukur oleh difraksi sinar X (XRD) melalui pergeseran puncak difraksi bentonit alam dengan bentonit teraktivasi asam. Pola ekspansi jarak antara lapis d001 pada bentonit teraktivasi asam menunjukkan jarak antar lapis silikat bentonit.

Keasaman permukaan bentonit merupakan jumlah situs asam (asam Brønsted dan asam Lewis) yang terikat pada tiap gram bentonit (Sinta dkk. 2015). Penentuan keasaman permukaan bentonit dilakukan dengan metode titrasi asam-basa. Titrasi merupakan bagian dari metode volumetri dimana situs asam bentonit direaksikan dengan $\mathrm{KOH}$ sampai volume tepat ekuivalen (zat-zat yang direaksikan tersebut tepat bereaksi habis). Nilai keasaman permukaan bentonit alam dan bentonit teraktivasi asam dapat dilihat pada Tabel 1 .

Berdasarkan data pada Tabel 1. menunjukkan bahwa bentonit alam tidak memiliki nilai keasaman permukaan $(0 \mathrm{mg} \mathrm{KOH} / \mathrm{g})$. Hal ini karena bentonit alam bersifat basa. Menurut Widihati (2008) adanya perlakuan aktivasi dengan asam dapat mengurangi oksida alkali dan alkali tanah seperti $\mathrm{Na}_{2} \mathrm{O}, \mathrm{K}_{2} \mathrm{O}$, $\mathrm{MgO}$ dan $\mathrm{CaO}$ karena telah terjadi substitusi ion $\mathrm{H}^{+}$, sehingga menyebabkan bertambahnya situs $\mathrm{H}^{+}$(asam Brønsted) pada bentonit. Aktivasi dengan asam pada konsentrasi tertentu juga dapat menyebabkan larutnya aluminium (dealuminasi) yang pada akhirnya dapat membentuk situs asam Lewis $\mathrm{Al}^{3+}$.

Pengujian $\mathrm{pH}$ suspensi solid bertujuan untuk menghitung $\mathrm{pH}$ atau keasaman ion-ion permukaan 
Tabel 2. Data pH Suspensi Solid Bentonit Alam dan Bentonit Teraktivasi Asam

\begin{tabular}{lc}
\hline \multicolumn{1}{c}{ Jenis Bentonit } & pH Suspensi Solid \\
\hline Bentonit Alam & 9,755 \\
Bentonit Teraktivasi $\mathrm{H}_{2} \mathrm{SO}_{4} 0,6 \mathrm{M}$ & 3,354 \\
Bentonit Teraktivasi $\mathrm{HCl}_{0,5 \mathrm{M}}$ & 3,965 \\
Bentoniit Teraktivasi $\mathrm{HNO}_{3} 0,1 \mathrm{M}$ & 7,039 \\
\hline
\end{tabular}

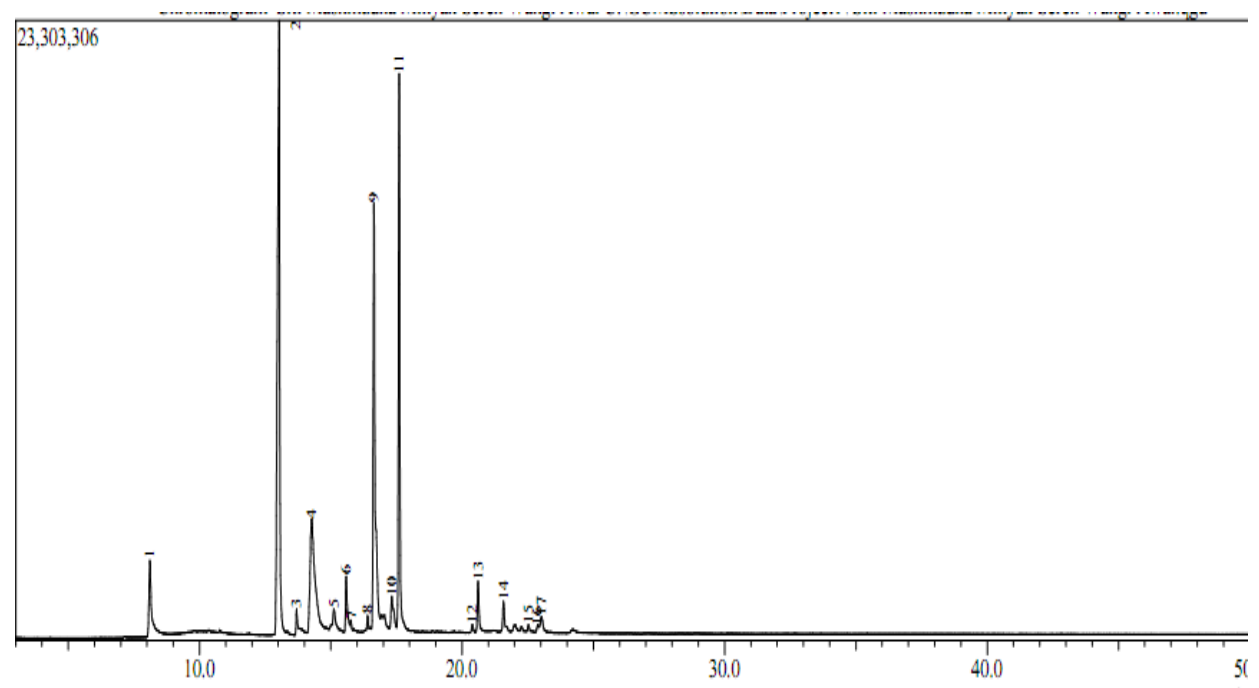

Gambar 3. Kromatogram Minyak Sereh Wangi Awal

bentonit alam dan bentonit teraktivasi yang larut dalam air. Keasaman ion-ion permukaan ini dipengaruhi oleh banyaknya jumlah $\mathrm{H}^{+}$yang larut dalam air. Berdasarkan data pada Tabel 2 dapat diketahui bahwa terdapat perbedaan $\mathrm{pH}$ suspensi solid antara bentonit alam dan bentonit teraktivasi asam. Bentonit teraktivasi $\mathrm{H}_{2} \mathrm{SO}_{4} 0,6 \mathrm{M}$ dan $\mathrm{HCl}$ 0,5 $\mathrm{M}$ memiliki $\mathrm{pH}$ yang lebih rendah dibanding bentonit alam dan bentonit teraktivasi $\mathrm{HNO}_{3} 0,1 \mathrm{M}$. Hal ini disebabkan karena adanya pengaruh dari aktivasi asam dan besarnya konsentrasi asam yang digunakan. Besarnya konsentrasi asam menyebabkan lebih banyak ion $\mathrm{H}^{+}$yang larut sehingga mempengaruhi nilai $\mathrm{pH}$ dari suspensinya. Menurut data pada Tonsil Optimum 210 FF yang merupakan standar acuan komersil dari bleaching earth, bentonit teraktivasi asam yang baik memiliki $\mathrm{pH}$ suspensi solid antara 2,2 $-4,8$.

\section{Uji Kinerja Bentonit terhadap Minyak Sereh Wangi}

Hasil analisis minyak sereh wangi awal dengan menggunakan GC-MS (Gambar 3) memperlihatkan bahwa terdapat 17 puncak kromatogram yang diperoleh dengan 4 puncak memiliki kelimpahan terbanyak. Pertama pada puncak kromatogram ke-2 memiliki persentase senyawa sebesar $33,70 \%$ dengan waktu retensi 13,034 menit diperkirakan sebagai senyawa sitronellal, selanjutnya pada puncak kromatogram ke-4 memiliki persentase senyawa sebesar 12,66\% dengan waktu retensi 14,262 menit diperkirakan sebagai senyawa isopulegol, pada puncak kromatogram ke- 9 memiliki persentase senyawa sebesar 18,62 \% dengan waktu retensi 16,643 menit diperkirakan sebagai senyawa sitronellol dan terakhir pada puncak kromatogram ke11 memiliki persentase senyawa sebesar $19,00 \%$ dengan waktu retensi 17,605 menit diperkirakan sebagai senyawa geraniol.

Berdasarkan data kromatogram diatas dapat diketahui bahwa minyak sereh wangi terdiri dari beberapa senyawa penyusun utama seperti sitronellal, sitronellol dan geraniol serta senyawa-senyawa lain seperti isopulegol, limonene, eugenol dan sebagainya.

Minyak Sereh Wangi yang telah diproses menggunakan bentonit alam dan bentonit teraktivasi asam dianalisis kembali menggunakan instrument GC-MS memperlihatkan bahwa telah terjadi perubahan persentase kandungan senyawa yang terdapat didalam minyak sereh wangi (Tabel 3). Pada Tabel 3 terlihat bahwa terjadi penurunan kadar sitronellal pada minyak sereh wangi dari $33,70 \%$ menjadi $33,15 \%$ dan $32,74 \%$ pada minyak dengan menggunakan bentonit alam dan bentonit teraktivasi $\mathrm{HNO}_{3} \quad 0,1 \mathrm{M}$, sedangkan pada minyak yang menggunakan bentonit teraktivasi $\mathrm{H}_{2} \mathrm{SO}_{4} 0,6 \mathrm{M}$ dan $\mathrm{HCl} 0,5 \mathrm{M}$ mengalami penurunan menjadi $1,68 \%$ dan $1,94 \%$. Penurunan kadar sitronellal ini disebabkan karena senyawa sitronellal sebagai salah satu komponen utama minyak sereh wangi merupakan senyawa yang sangat mudah bereaksi karena adanya ikatan rangkap dan tergolong senyawa aldehid (Kaniawati dkk. 2004). Selain itu pada Tabel 3 terlihat adanya peningkatan kadar isopulegol 
Tabel 3. Hasil kromatogram minyak sereh wangi awal dan minyak sereh wangi menggunakan adsorben bentonit alam dan teraktivasi asam

\begin{tabular}{|c|c|c|c|c|c|c|c|c|}
\hline \multirow[b]{2}{*}{ Sampel } & \multicolumn{2}{|c|}{ Sitronellal } & \multicolumn{2}{|c|}{ Isopulegol } & \multicolumn{2}{|c|}{ Sitronellol } & \multicolumn{2}{|c|}{ Geraniol } \\
\hline & $\begin{array}{l}\text { Waktu } \\
\text { Retensi } \\
\text { (menit) }\end{array}$ & $\begin{array}{c}\text { Persentase } \\
(\%)\end{array}$ & $\begin{array}{l}\text { Waktu } \\
\text { Retensi } \\
\text { (menit) }\end{array}$ & $\begin{array}{c}\text { Persentase } \\
(\%)\end{array}$ & $\begin{array}{l}\text { Waktu } \\
\text { Retensi } \\
\text { (menit) }\end{array}$ & $\begin{array}{c}\text { Persentase } \\
(\%)\end{array}$ & $\begin{array}{l}\text { Waktu } \\
\text { Retensi } \\
\text { (menit) }\end{array}$ & $\begin{array}{c}\text { Persentase } \\
(\%)\end{array}$ \\
\hline Minyak awal & 13,034 & 33,70 & 14,262 & 12,66 & 16,643 & 18,62 & 17,605 & 19,00 \\
\hline $\begin{array}{l}\text { Bentonit } \\
\text { Alam }\end{array}$ & 13,024 & 33,15 & 14,270 & 14,05 & 16,636 & 18,29 & 17,600 & 18,31 \\
\hline $\begin{array}{l}\text { Bentonit Teraktivasi } \\
\mathrm{H}_{2} \mathrm{SO}_{4} 0,6 \mathrm{M}\end{array}$ & 12,923 & 1,68 & 14,256 & 30,11 & 16,637 & 22,32 & 17,595 & 21,46 \\
\hline $\begin{array}{l}\text { Bentonit Teraktivasi } \\
\mathrm{HCl} 0,5 \mathrm{M}\end{array}$ & 12,920 & 1,94 & 14,253 & 32,70 & 16,631 & 23,10 & 17,591 & 21,72 \\
\hline $\begin{array}{l}\text { Bentonit Teraktivasi } \\
\mathrm{HNO}_{3} 0,1 \mathrm{M}\end{array}$ & 13,022 & 32,74 & 14,268 & 14,34 & 16,636 & 18,29 & 17,598 & 18,47 \\
\hline
\end{tabular}

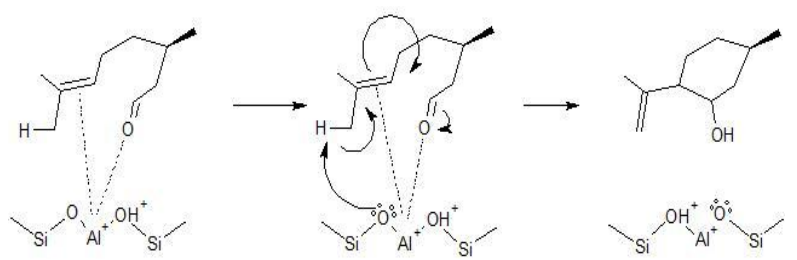

Gambar 4. Mekanisme reaksi siklisasi sitronellal menggunakan katalis bentonit teraktivasi asam.

pada minyak sereh wangi dari $12,66 \%$ menjadi $14,05 \%$ pada bentonit alam, $30,11 \%$ pada bentonit teraktivasi $\mathrm{H}_{2} \mathrm{SO}_{4} \quad 0,6 \mathrm{M}, 32,70 \%$ pada bentonit teraktivasi $\mathrm{HCl} 0,5 \mathrm{M}$ dan $14,34 \%$ pada bentonit teraktivasi $\mathrm{HNO}_{3} 0,1 \mathrm{M}$.

Isopulegol adalah senyawa turunan sitronellal yang biasa digunakan sebagai bahan baku pada industri parfum. Menurut Devakumar et al. (1977) dalam Kaniawati dkk. (2004), sitronellal pada suasana asam memiliki kecenderungan untuk membentuk senyawa siklis seperti isopulegol. Sitronellal dapat mengalami siklisasi menggunakan berbagai katalis seperti silika gel, asam asetat anhidrida, karbon aktif dan lain-lain menjadi campuran isopulegol. Hal ini diperkuat dengan penelitian yang telah dilakukan Priatmoko \& Sastrohamidjojo (1990) yang telah melakukan siklisasi sitronellal menjadi isopulegol dengan berbagai katalis asam. Katalis asam yang digunakan antara lain zeolit, bentonit, lempung aktif, $\mathrm{HCl}$ pekat, $\mathrm{H}_{2} \mathrm{SO}_{4}$ pekat dan asam asetat anhidrida.

Berdasarkan hasil penelitian ini diperoleh bahwa bentonit yang digunakan pada penelitian ini dapat dikatakan berperan sebagai katalis dalam proses pembentukan senyawa isopulegol yang disebut reaksi siklisasi sitronellal pada minyak sereh wangi. Penelitian lain yang juga menyatakan bahwa bentonit dapat berperan sebagai katalis dalam reaksi konversi senyawa sitronellal menjadi isopulegol dilakukan oleh Fatimah dkk. (2008) dengan menggunakan katalis $\mathrm{TiO}_{2} / \mathrm{SiO}_{2}$-Montmorillonit. Menurut MäkiArvela et al. (2004) reaksi siklisasi sitronellal dikatalis oleh situs asam lewis dan bronsted yang terdapat pada permukaan bentonit. Situs asam Lewis ini terkait dengan adanya ikatan koordinasi tak jenuh yang berasal dari ion logam sedangkan situs asam bronsted terkait dengan adanya pertukaran ion $\mathrm{OH}$ positif pada permukaan bentonit.

Banyaknya jumlah situs asam Lewis dan asam Brønsted dapat dilihat dari nilai keasaman permukaan bentonit, namun berdasarkan data nilai keasaman permukaan bentonit teraktivasi asam terlihat bahwa tidak ada perbedaan nilai keasaman permukaan bentonit teraktivasi $\mathrm{H}_{2} \mathrm{SO}_{4} 0,6 \mathrm{M}, \mathrm{HCl} \quad 0,5 \mathrm{M}$ dan $\mathrm{HNO}_{3}$ 0,1 M. Sedangkan berdasarkan data analisis GC-MS terlihat bahwa reaksi siklisasi sitronellal menjadi isopulegol yang paling besar terdapat pada minyak yang telah diproses menggunakan bentonit teraktivasi $\mathrm{H}_{2} \mathrm{SO}_{4} 0,6 \mathrm{M}$ dan bentonit teraktivasi $\mathrm{HCl}$ 0,5 M. Hal ini diperkirakan karena banyaknya jumlah $\mathrm{H}^{+}$yang tedapat pada permukaaan bentonit yang dapat berperan sebagai sisi asam bronsted yang diperkirakan bertindak dominan dalam reaksi siklisasi sitronellal, hal ini didukung oleh data $\mathrm{pH}$ suspensi solid dari bentonit teraktivasi $\mathrm{H}_{2} \mathrm{SO}_{4} 0,6 \mathrm{M}$ dan bentonit teraktivasi $\mathrm{HCl} 0,5 \mathrm{M}$ yang masingmasing memiliki pH suspensi solid sebesar 3 .

Adapun mekanisme siklisasi sitronellal menjadi isopulegol menggunakan katalis bentonit teraktivasi asam diperkirakan terlihat pada Gambar 4.

Reaksi siklisasi katalitik diperkirakan berlangsung melalui 5 tahapan sebagai berikut: Tahap 1: Molekul reaktan sitronellal melakukan migrasi melewati bidang antar muka cair-padat sebelum dapat bertemu dengan situs aktif untuk dapat teradsoprsi dan teraktifkan. Tahap 2: Molekul reaktan sitronellal terlebih dahulu mengalami peregangan molekul pada permukaan adsorben katalis sampai terjadi disosiasi ikatan. Tahap 3: Elektron menyendiri pada atom $\mathrm{O}$ dan elektron $\pi$ pada gugus alkena terikat pada sisi 
asam Lewis $\left(\mathrm{Al}^{3+}\right)$ dari katalis. Dalam hal ini situs aktif asam Lewis katalis berperan sebagai elektrofil yang mengadisi ikatan rangkap karbonil dan ikatan rangkap karbon pada gugus alkena. Dilanjutkan protanasi melalui sisi asam Brønsted $\left(\mathrm{H}^{+}\right)$terhadap atom $\mathrm{O}$ dan menginisiasi reaksi siklisai membentuk isopulegol. Tahap 4: Molekul produk isopulegol kembali bermigrasi melewati bidang antar muka cairpadat meninggalkan permukaan katalis. Tahap 5: Transfer produk isopulegol ke dalam fase cair, dan katalis teregenerasi kembali tanpa mengalami perubahan (Iftitah et al. 2004).

\section{KESIMPULAN}

Sebanyak Berdasarkan penelitian ini diperoleh kesimpulan bahwa Penggunaan bentonit alam dan bentonit teraktivasi asam pada minyak sereh wangi Kabupaten Gayo Lues Provinsi Aceh berperan sebagai katalis untuk mengubah senyawa sitronellal menjadi senyawa isopulegol. Senyawa isopulegol mengalami peningkatan dari $12,66 \%$ menjadi $14,05 \%$ pada bentonit alam, $30,11 \%$ pada bentonit teraktivasi $\mathrm{H}_{2} \mathrm{SO}_{4} 0,6 \mathrm{M}, 32,70 \%$ pada bentonit teraktivasi $\mathrm{HCl}$ $0,5 \mathrm{M}$ dan $14,24 \%$ pada bentonit teraktivasi $\mathrm{HNO}_{3}$ $0,1 \mathrm{M}$.

\section{Ucapan Terima Kasih}

Penulis menghaturkan terimakasih kepada LPPM UIN Sunan Kalijaga Yogyakarta yang telah mendukung dan mendanai penelitian ini.

\section{DAFTAR PUSTAKA}

Devakumar, C., Narayan, M.R. \& Khan, M.N.A., (1977). Synthetic product from oil of citronella. Indian Perfumer. 21(3): 139-145.

Fatimah, I., Rubiyanto, D. \& Huda, T. (2008). Peranan katalis $\mathrm{TiO}_{2} / \mathrm{SiO}_{2}$-montmorillonit pada reaksi konversi sitronelal menjadi isopulegol. Reaktor. 12(2): 83-89.

Iftitah, E.D.., Sastrohamidjojo, H. \& Muchalal, M. (2004). Study of catalytic of (+)-citronellal with $\mathrm{Zn} / \gamma$-alumina. Indonesian Journal of Chemistry. 4(3): 192-196.

Kaniawati, D., Kadarohman, A. \& Dwiyanti, G. (2004). Konversi Sitronelal Hasil Isolasi Minyak sereh Wangi Menjadi Sitronellol dan Isopulegol. Seminar Nasional Penelitian dan Pendidikan Kimia. Bandung: FMIPA, UPI.

Mäki-Arvela, P., Kumar, N., Nieminen, V., Sjöholm, R., Salmi, T. \& Murzin, D.Y., (2004).
Cyclization of citronellal over zeolites and mesoporous materials for production of isopulegol. Journal of Catalysis. 225(1): 155169.

Marwati, T., Rusli, M.S., Noor, E. \& Mulyono, E. (2005). Peningkatan mutu minyak daun cengkeh melalui proses pemurnian. Jurnal Penelitian Pascapanen Pertanian. 2(2): 45-52

Morris, M.C., Mc Murdie, H.F. \& Evans, E.H. (1981). Standar X-Ray Difraction Powder Patterns. National Bureau of Standards.

Murray, H.H. (2007). Applied clay mineralogy. Developments in clay science, 2. London: Elsevier.

Priambodo, N.G. (2014). Pemurnian Minyak Nilam Menggunakan Bentonit Teraktivasi Asam Klorida. Skripsi. Fakultas Sains dan Teknologi. Yogyakarta, UIN Sunan Kalijaga.

Priatmoko \& Sastrohamidjojo, H. (1990). Sintesis mentol dari sitronellal hasil isolasi minyak sereh. Fakultas Pasca Sarjana. Yogyakarta, Universitas Gadjah Mada.

Purwaningsih, E., Supartono, S. \& Harjono, H. (2012). Reaksi transesterifikasi minyak kelapa dengan metanol menggunakan katalis bentonit. Indonesian Journal of Chemical Science. 1(2): 133-139.

Rahman, A. (2015). Serai Wangi Tingkatkan Perekonomian Masyarakat gayo Lues. http://obsessionnews.com/serai-wangitingkatkan-perekonomian-masyarakat-gayolues/ di akses tgl 31 Maret 2015 pukul 15.40 wib

Sastrohamidjojo, H., 2004. Kimia Minyak Atsiri. Yogyakarta : Gadjah Mada University Press.

Sinta, I.N., Suarya, P. \& Santi, S.R. (2015). Adsorpsi Ion Fosfat oleh Lempung Teraktivasi Asam Sulfat. Jurnal Kimia. 9(2): 217-225.

Tan, K.H. (1992). Dasar-dasar Kimia Tanah, Edisi Pertama, Penerjemah: Goenadi, D.H., Yogyakarta: Gadjah Mada University Press.

Widihati, I.A.G. (2008). Adsorpsi anion Cr(VI) oleh batu pasir teraktivasi asam dan tersalut $\mathrm{Fe}_{2} \mathrm{O}_{3}$. Jurnal Kimia. 2(1): 25-30.

Wijaya, K., Tahir, I. \& Mudasir. (2003). Sintesis dan karakterisasi Montmorilonit Terpilar serta Aplikasinya sebagai Fotokatalis, bahan foto fungsional dan adsorben. Berkala Ilmiah MIPA. 13(2): 1-16. 